DOI 10.22460/jpmi.v1i3.219-228

\title{
MENINGKATKAN KEMAMPUAN KOMUNIKASI MATEMATIK SISWA SEKOLAH MENENGAH PERTAMA MELALUI PENDEKATAN CONTEXTUAL TEACHING AND LEARNING
}

\author{
Inur Nurmala ${ }^{1}$, Wahyu Hidayat ${ }^{2}$, Heris Hendriana ${ }^{3}$ \\ 1,2,3 IKIP Siliwangi, J1. Terusan Jenderal Sudirman, Cimahi, Jawa Barat, Indonesia \\ inurmala8@gmail.com¹,wahyu@ikipsiliwangi.ac.id², herishen@ikipsiliwangi.ac.id ${ }^{3}$
}

\begin{abstract}
This research is based on the low level of mathematical communication ability of Junior High School students in West Bandung regency, so that requires a solution that can solve the problem. One of the alternatives in learning used is Contextual Teaching and Learning (CTL) approach. This study aims to examine the effect of Contextual Teaching and Learning (CTL) approach to improving mathematic communication ability of junior high school students. The method used in this study was experimental quasi-experimentation with the non-equivalent petest-posttest control group design, ie before the two groups were given pretest, at the end of the study the two groups were given a post test. The population in this study is all junior high school students in West Bandung regency whose characteristics have low mathematical communication skills, from all junior high schools in West Bandung Regency selected SMP Bhakti Mulya Batujajar representing the characteristics of the population. The sample consists of two classes, namely class VII-C as the experimental class and class VII-D as the control class. Data collection in this research in the form of description test as much as 5 problem of mathematic communication ability which have been tested, then data score of mathematic communication ability is analyzed using SPSS 20 software and Minitab software. 17. From the results of the study, both from the results of data analysis and hypothesis testing, it can be concluded that the improvement of mathematical communication skills of junior high school students in West Bandung regency whose learning using CTL approach is better than that using conventional learning.
\end{abstract}

Keywords: Mathematical Communication, Contextual Teaching and Learning (CTL)

\section{Abstrak}

Penelitian ini dilatar belakangi oleh masih rendahnya kemampuan komunikasi matematik siswa Sekolah Menengah Pertama (SMP) di Kabupaten Bandung Barat, sehingga memerlukan penyelesaian yang dapat mengatasi permasalahan tersebut. Salah satu alternatif dalam pembelajaran yang digunakan adalah pendekatan Contextual Teaching and Learning (CTL). Penelitian ini bertujuan untuk menelaah hasil pengaruh pendekatan Contextual Teaching and Learning (CTL) terhadap peningkatan kemampuan komunikasi matematik siswa SMP. Metode yang digunakan dalam peneitian ini adalahkuasi eksperimen dengan penelitian dalam bentuk the non-equivalent petest-posttest control group design, yaitu sebelum penelitian kedua kelompok diberi pretes, di akhir pembelajaran kedua kelompok diberi tes akhir (postes). Populasi dalam penelitian ini adalah seluruh siswa SMP di Kabupaten Bandung Barat yang karakteristiknya memiliki kemampuan komunikasi matematik yang rendah, dari seluruh SMP di Kabupaten Bandung Barat dipilihlah SMP Bhakti Mulya Batujajar yang mewakili karakteristik populasi. Sampelnya terdiri dari dua kelas, yaitu kelas VII-C sebagai kelas eksperimen dan kelas VII-D sebagai kelas kontrol. Pengumpulan data dalam penelitian ini berupa tes uraian sebanyak 5 soal kemampuan komunikasi matematik yang telah diujicobakan, kemudian data skor kemampuan komunikasi matematik tersebut dianalisis menggunakan software SPSS 20 dan software Minitab. 17. 
Dari hasil penelitian, baik dari hasil analisis data maupun pengujian hipotesis, maka dapat disimpulkan bahwa peningkatan kemampuan komunikasi matematik siswa SMP di Kabupaten Bandung Barat yang pembelajarannya menggunakan pendekatan $C T L$ lebih baik daripada yang menggunakan pembelajaran konvensional.

Kata Kunci: Komunikasi Matematik, Contextual Teaching and Learning (CTL)

How to cite: Nurmala, I., Hidayat, W., \& Hendriana, H. (2018). Meningkatkan Kemampuan Komunikasi Matematik Siswa Sekolah Menengah Pertama melalui Pendekatan Contextual Teaching and Learning. JPMI - Jurnal Pembelajaran Matematika Inovatif,1 (1), 21-28.

\section{PENDAHULUAN}

Kemampuan komunikasi merupakan suatu hal yang sangat penting dalam berinteraksi dan bersosialisasi, karena dengan komunikasi manusia dapat saling berhubungan baik secara lisan ataupun tulisan.

Menurut National of Teachers of Mathematics (Ruqoyyah, 2015) salah satu rumusan tujuan pembelajaran matematika adalah belajar untuk berkomunikasi. Selanjutnya, kemampuan komunikasi matematik adalah suatu kompetensi matematik yang esensial untuk dimiliki dan dikembangkan pada siswa sekolah menengah (Hidayat, 2013). Menurut Syaban (Nurismayanti, 2015) komunikasi matematik merupakan refleksi pemahaman matematika dan merupakan bagian dari daya tarik matematis. Siswa-siswa yang mempelajari matematika seakan-akan mereka berbicara dan menulis tentang apa yang sedang mereka kerjakan. Mereka dilibatkan secara aktif dalam mengerjakan matematika, diminta untuk memikirkan ide-ide, atau berbicara dan mendengarkan siswa lain dalam berbagai ide, pendapat, dan solusi.

Pentingnya pemilikan kemampuan komunikasi matematik antara lain: a) matematika adalah merupakan bahasa esensial, bukan hanya sebagai alat untuk berpikir, menemukan rumus, menyelesaikan masalah, dan menyimpulkan, tetapi matematika juga sebagai suatu alat yang sangat bernilai dalam menyatakan beragam idea secara jelas, teliti, dan tepat, dan b) Matematika dan belajar matematika adalah jantungnya kegiatan social, misalnya dalam pembelajaran matematika interaksi antara guru dan siswa, interaksi antar siswa, dan antara bahan ajar matematika dan siswa merupakan faktor penting untuk memajukan potensi siswa. (Qodariyah \& Hendriana, 2015)

Kemampuan berkomunikasi dalam pembelajaran matematika di sekolah menengah pertama kurang mendapat perhatian dari para guru. Guru cenderung menekankan pada kemampuan berhitung, pemecahan masalah, dan penalaran (Haji \& Abdullah, 2016). Sehingga kemampuan komunikasi matematika siswa lemah.

Fakta lain menyatakan rendahnya kemampuan komunikasi matematik menurut hasil penelitian dari TIMSS (Nursanti, 2015), prestasi siswa di Indonesia untuk bidang matematika tergolong rendah, menempatkan siswa Indonesia pada peringkat 36 dari 48 negara yang di evaluasi. Siswa Indonesia yang diteliti pada kelas 4 dan kelas 8 hanya memperoleh 397 dari skala internasional 500. Hasil dari TIMSS ini menunjukan prestasi siswa dalam pelajaran matematika jauh tertinggal dari negara lain. 
Salah satu solusi dari permasalahan-permasalahan di atas adalah pembelajaran matematika di sekolah dengan menggunakan pendekatan Contextual Teaching and Learning yang diupayakan dapat membuat siswa untuk aktif, kreatif dan berpikir kritis dalam mencapai kompetensi yang diharapkan.

Contextual Teaching and Learning adalah suatu sistem pengajaran yang cocok dengan otak yang menghasilkan makna dengan menghubungkan muatan akademik dengan konteks dari kehidupan sehari-hari siswa (Jhonson, 2011). Pendekatan kontekstual adalah pembelajaran yang dimulai dengan mengambil permasalahan-permasalahan kehidupan sehari-hari atau permasalahan yang disimulasikan, kemudian melalui dialog, diskusi, tanya jawab serta representasi diangkat ke dalam konsep yang akan dipelajari dan di bahas oleh peserta didik melalui bimbingan, fasilitas serta negosiasi pendidiknya (Hidayat, 2014). Pendekatan Contextual Teaching and Learning merupakan suatu konsep belajar yang membantu guru mengaitkan antara materi yang diajarkan dengan situasi dunia nyata siswa yang mendorong siswa membuat hubungan antara pengetahuan yang dimilikinya dengan penerapannya dalam kehidupan sehari-hari.

Berdasarkan uraian di atas, maka dalam hal ini peneliti merumuskan masalah yaitu apakah pencapaian dan peningkatan kemampuan komunikasi matematik siswa SMP di Kabupaten Bandung Barat yang pembelajarannya menggunakan pendekatan Contextual Teaching and Learning lebih baik daripada menggunakan pembelajaran biasa?

Sejalan dengan permasalahan diatas maka secara garis besar penelitian ini bertujuan untuk menelaah pencapaian dan peningkatan kemampuan komunikasi matematik siswa SMP di Kabupaten Bandung Barat yang pembelajarannya menggunakan pendekatan contextual teaching and learning lebih baik daripada menggunakan pembelajaran biasa serta langkahlangkah implementasi pembelajaran contextual teaching and learning di lapangan.

\section{METODE}

Metode dalam penelitian ini adalah kuasi eksperimen, dimana ada dua kelas sampel penelitian yaitu kelas eksperimen dengan menggunakan pendekatan contextual teaching and learning dan kelas kontrol dengan pembelajaran konvensional. Adapun sampel dalam penelitian ini terdiri dari dua kelas, yaitu: siswa kelas VII SMP Bhakti Mulya Batujajar yang pilih secara purposive sampling Desain yang digunakan dalam penelitian ini yaitu pretest-posttest-control group design. Desain penelitian ini digunakan karena penelitian ini menggunakan kelas kontrol dan kelas eksperimen, tes dilakukan dua kali yaitu sebelum proses pembelajaran, yang disebut pretest dan sesudah proses pembelajaran yang disebut posttest. Desain penelitian digambarkan sebagai berikut: (Lestari \& Yudhanegara, 2015)

Keterangan:

$$
\text { O } \mathrm{O} \text { O }
$$

$\mathrm{O}=$ Pretes $=$ postes

$\mathrm{X}=$ Pendekatan Contextual Teaching and Learning

Instrumen dalam penelitian ini hanya menggunakan instrumen tes, yaitu berupa tes uraian untuk mengukur kemampuan komunikasi matematik siswa. Untuk analisis data peneliti menggunakan 
bantuan program software SPSS 20, software Minitab. 17, dan Microsoft Excel 2010. Untuk mengetahui seberapa besar peningkatan kemampuan komunikasi matematik siswa sebelum dan setelah kegiatan pembelajaran, dilakukan analisis skor gain ternormalisasi yang dihitung dengan menggunakan rumus sebagai berikut :

$$
\mathrm{g}=\frac{\text { skor tes akhir-skor tes awal }}{\text { skor maksimum ideal-skor tes awal }}
$$

Tingkat perolehan skor gain ternormalisasi dikelompokkan kedalam tiga kategori, yaitu :
$0,70<(\mathrm{g})$
: Tinggi
$0,30 \leq(\mathrm{g}) \leq 0,70$
: Sedang
$(\mathrm{g})<0,30$
: Rendah

\section{HASIL DAN PEMBAHASAN}

\section{Hasil}

Rekapitulasi hasil penelitian kemampuan komunikasi matematik siswa antara kelas yang pembelajarannya menggunakan pendekatan contextual teaching and learning dengan pembelajaran konvensional disajikan dalam tabel berikut:

Tabel 1. Deskripsi Hasil Penelitian Kemampuan Komunikasi Matematik Siswa

\begin{tabular}{lcccccc}
\hline & \multicolumn{3}{c|}{ Pendekatan CTL } & \multicolumn{3}{c}{ Pendekatan Konvensional } \\
\cline { 2 - 7 } & Pretes & Postes & N-Gain & Pretes & Postes & N-Gain \\
\hline $\mathbf{n}$ & & 32 & & & 30 & \\
\hline $\boldsymbol{x}_{\boldsymbol{m a x}}$ & 7 & 18 & 0,85 & 7 & 14 & 0,65 \\
\hline $\boldsymbol{x}_{\boldsymbol{m i n}}$ & 0 & 9 & 0,23 & 0 & 7 & 0,14 \\
\hline$\overline{\boldsymbol{x}}$ & 4,03 & 12,47 & 0,51 & 3,17 & 9,90 & 0,39 \\
& & & & & & \\
\hline $\mathbf{S}$ & 1,89 & 2,23 & 0,16 & 1,74 & 1,95 & 0,13
\end{tabular}

Keterangan : Skor Maksimal Ideal (SMI) kemampuan komunikasi matematik $=20$

Berdasarkan Tabel 1, dapat dikemukakan deskripsi hasil penelitian kemampuan komunikasi mateamtik sebagai berikut: 1) selisih rata-rata pretes kelas eksperimen dan kelas kontrol tidak terlalu jauh, yaitu sebesar 0,86. Maka dapat diambil kesimpulna kemampuan awal komunikasi matematik kedua kelas tidak terlalu jauh berbeda. 2) rata-rata dan simpangan baku postes kemampuan komunikasi matematik kelas eksperimen lebih besar dibanding kelas kontrol. 3) rata-rata n-gain kelas eksperimen lebih baik daripada kelas kontrol, sehingga peningkatan kemampuan komunikasi matematik kelas eksperimen lebih baik dibanding kelas kontrol pada kategori sedang. 
Untuk mendukung deskripsi peningkatan kemampuan komunikasi matematik yang telah dijelaskan, maka dilakukan analisis data kemampuan komunikasi matematik siswa melalui uji statistik menggunakan software SPSS. 20 dan Minitab. 16

\section{Analisis Data Pretes Kemampuan Komunikasi Matematik}

Hipotesis:

$H_{0}: \mu_{1}=\mu_{2}$

$H_{1}: \mu_{1} \neq \mu_{2}$

Kriteria pengujian:

Jika nilai Sig $>0,05$ maka $H_{0}$ diterima

Tabel 2. Hasil Analisis Uji Mann-Whitney Data Pretes

\begin{tabular}{ll}
\hline Signifikansi & Interpretasi \\
\hline 0,056 & $\mathrm{H}_{0}$ diterima
\end{tabular}

(Diambil dari output SPSS.20)

Berdasarkan Tabel 2 terlihat bahwa nilai signifikansi adalah 0,056 atau lebih besar dari 0,05 sehingga $H_{0}$ diterima, dapat disimpulkan bahwa kemampuan awal komunikasi matematik siswa kedua kelas sama.

\section{Analisis Data Postes Kemampuan Komunikasi Matematik}

Hipotesis:

$H_{0}: \mu_{1}=\mu_{2}$

$H_{1}: \mu_{1}>\mu_{2}$

Kriteria pengujian:

Jika $P$-Value $>0,05$ maka $H_{0}$ diterima

Tabel 3. Hasil Analisis Uji Signifikansi Perbedaan Dua Rata-Rata Data Postes

\begin{tabular}{|lllll|}
\hline \multicolumn{4}{|c|}{ Two-sample T for Eksperimen vs Kontrol } \\
& $\mathrm{N}$ & Mean & StDev & SE Mean \\
Eksperimen & 32 & 12.47 & 2.23 & 0.39 \\
Kontrol & 30 & 9.90 & 1.95 & 0.36 \\
& P-Value $=0.000$ & $\mathrm{DF}=60$ \\
\hline
\end{tabular}

(Diambil dari output Minitab. 17)

Berdasarkan Tabel 3 terlihat bahwa $P$-Value $<0,05$ maka $H_{1}$ diterima. Sehingga dapat disimpulkan bahwa kemampuan komunikasi matematik siswa yang pembelajarannya 
menggunakan pendekatan $C T L$ lebih baik dari siswa yang menggunakan pembelajaran konvensional.

\section{Analisis Data N-Gain Kemampuan Komunikasi Matematik}

Hipotesis:

$H_{0}: \mu_{1}=\mu_{2}$

$H_{1}: \mu_{1}>\mu_{2}$

Kriteria pengujian:

Jika $P$-Value $>0,05$ maka $H_{0}$ diterima

Tabel 4. Hasil Analisis Uji Perbedaan Rata-rata N-gain Kemampuan Komunikasi Matematik

\begin{tabular}{|lcccc|}
\hline \multicolumn{4}{|c|}{ Two-sample $\mathrm{T}$ for Eksperimen vs Kontrol } \\
& $\mathrm{N}$ & Mean & StDev & SE Mean \\
Eksperimen & 32 & 0.555 & 0.147 & 0.026 \\
Kontrol & 30 & 0.448 & 0.106 & 0.019 \\
& P-Value $=0.001$ & DF $=60$ \\
\hline
\end{tabular}

(Diambil dari output Minitab. 17)

Berdasarkan Tabel 4 P-Value $<0,05$ maka $H_{l}$ diterima. Sehingga dapat disimpulkan peningkatan kemampuan komunikasi matematik siswa yang pembelajarannya menggunakan pendekatan CTL lebih baik dari pembelajaran konvensional. Peningkatan dan pencapaian kemampuan komunikasi matematik siswa yang pembelajarannya menggunakan pendekatan Contextual Teaching and Learning (CTL) maupun melalui pembelajaran konvensional tersaji pada gambar 1 berikut.

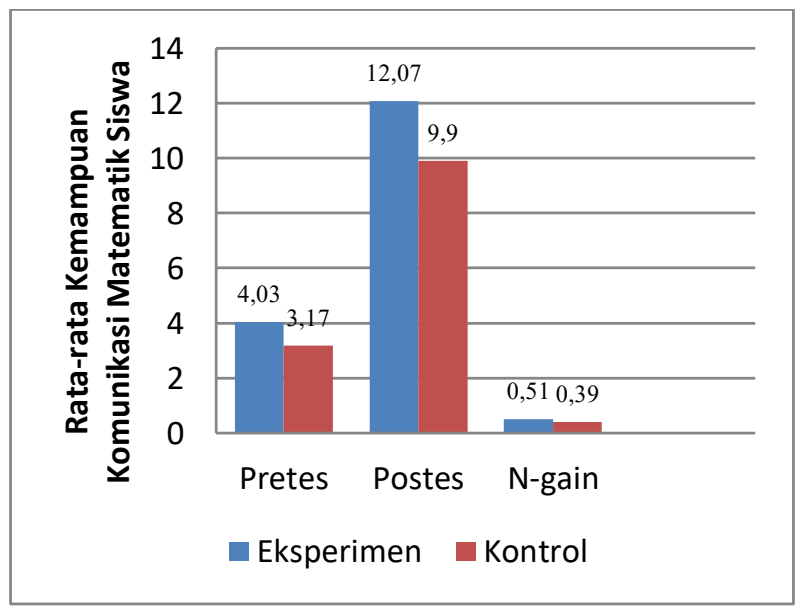

Gambar 1. Pencapain dan Peningkatan Kemampuan Komunikasi Matematik Siswa 


\section{Pembahasan}

Penelitian ini dilakukan selama kurang lebih satu bulan atau 8 kali pertemuan pada masingmasing kelas, di tambah dua pertemuan untuk pretes dan postes. Kedua kelas memperoleh perlakuan yang berbeda, pada kelas eksperimen diberikan perlakuan dengan pendekatan contextual teaching and learning dan untuk kelas kontrol diberikan perlakuan dengan pembelajaran konvensional, tetapi dengan materi yang sama yaitu segitiga dan segi empat.

Kegiatan pembelajaran kelas eksperimen yaitu menggunakan pendekatan $C T L$, semua langkahlangkah implementasi dalam kegiatan pembelajaran sesuai dengan karakteristik CTL. Pada kegiatan awal pembelajaran di kelas eksperimen siswa diberikan stimulus pertanyaan yang berkaitan dengan materi yang akan diajarkan pada setiap pertemuannya, kemudian siswa dikelompokkan secara heterogen dan siswa mengerjakan Lembar Aktivitas Siswa (LAS) berbasis pendekatan CTL setiap pertemuannya secara berkelompok. Kemudian, setelah itu hasilnya dipresentasikan di depan kelas oleh perwakilan salah satu siswa dari satu atau dua kelompok untuk setiap pertemuannya, siswa yang lain diberikan motivasi agar aktif mengevaluasi jawaban kelompom yang mempresentasikan hasil diskusinya. Meskipun pada kenyataannya tidak semua siswa dapat terlibat aktif. Setelah itu dengan Tanya jawab guru mengarahkan semua siswa pada kesimpulan mengenai materi untuk setiap pertemuannya dan kegiatan akhir dari setiap pembelajaran adalah penialaian atau evaluasi.

Sedangkan untuk kelas kontrol, semua langkah-langkah kegiatan pembelajarannya sesuai dengan pembelajaran biasa yang digunakan di sekolah tersebut. Adapun kegiatan pembelajarannya antara lain adalah ceramah, diskusi, dan tanya-jawab. Untuk kelas kontrol pada setiap pembelajaran tidak diberikan LAS seperti kelas eksperimen karena pembelajaran yang digunakan berbeda dengan kelas eksperimen seperti yang telah dijelaskan sebelumnya. Tetapi, kegiatan akhir dari setiap pembelajarannya sama yaitu penilaian atau evaluasi.

Berdasarkan pengalaman yang dialami peneliti pada saat proses penelitian, ditemukan beberapa kelebihan salah satunya adalah siswa menjadi lebih aktif dalam proses pembelajaran. Adapun kendala yang dialami pada saat penelitian salah satunya siswa belum terbiasa dengan pendekatan yang diterapkan oleh peneliti sehingga siswa cenderung lebih banyak bertanya dalam menyelesaikan LAS kepada peneliti tanpa berusaha berdiskusi dahulu bersama kelompoknya. Hambatan tersebut tentunya akan berdampak pada pencapaian dan peningkatan ynag kurang maksimal, akan tetapi peneliti berusaha mengatasi hambatan tersebut dengan memotivasi siswa agar mampu menyelesaikan permasalahan tersebut.

Setelah megetahui kemampuan awal siswa dan dilakukan perlakuan, selanjutnya dilakukan postes. Berdasarkan Tabel 1 hasil postes dan analisis mengenai skor postes antara kelas eksperimen dan kelas kontrol, jika dilihat dari rata-rata kedua kelas tersebut menunjukan selisih sebesar 2,57. Sehingga dapat disimpulkan bahwa pencapaian dan peningkatan kemampuan komunikasi matematik siswa yang pembelajarannya menggunakan pendekatan CTL lebih baik dari siswa yang menggunakan pembelajaran konvensional.

\section{KESIMPULAN}

Berdasarkan analisis data dan pembahasan hasil penelitian yang telah diuraikan sebelumnya, diperoleh kesimpulan bahwa pencapaian dan peningkatan kemampuan komunikasi matematik yang pembelarannya menggunakan pendekatan Contextual Teaching and Learning (CTL) lebih baik dari siswa yang menggunakan cara pembelajaran konvensional. 


\section{DAFTAR PUSTAKA}

Haji, S., \& Abdullah, I. M. (2016). Peningkatan Kemampuan Komunikasi Matematik melalui Pembelajaran Matematika Realistik. Jurnal Infinity Vol 5 (1), 42-49.

Hidayat, W. (2013). Mengembangkan Kemampuan Komunikasi dan Berpikir Logis Matematik Siswa SMA melalui Pembelajaran Berbasis Masalah. Prosiding Seminar Nasional Matematika dan Pendidikan Matematika. Vol 1, pp. 104-113. Bandung: STKIP Siliwangi.

Hidayat, W. (2014). Mengembangkan Retensi Kemampuan Berpikir Tingkat Tinggi Matematis Siswa SMP melalui Pendekatan Kontekstual. Prosiding Seminar Nasional Pendidikan Matematika. Vol 2, pp. 32-44. Bandung: STKIP Siliwangi Bandung.

Jhonson, E. B. (2011). Contextual Teaching and Learning. Bandung: Kaifa.

Lestari, K. E., \& Yudhanegara, M. R. (2015). Penelitian Pendidikan Matematika. Bandung: PT Refika Aditama.

Nurismayanti. (2015). Mengembangkan Kemampuan Komunikasi dan Pemecahan Masalah serta Kepercayaan Diri Siswa SMA melalui Pendekatan Berbasih Masalah. Tesis STKIP Siliwangi Bandung. Tidak diterbitkan.

Nursanti, I. (2015). Meningkatakna Kemampuan Komunikasi Matematis dan Self Confidence Siswa dengan Menggunakan Pendekatan Somatis, Auditori, Visua, dan Intelektual (SAVI). Skripsi STKIP Siliwangi. Tidak diterbitkan.

Qodariyah, L., \& Hendriana, H. (2015). Mengembangkan Kemampuan Komunikasi dan Disposisi Matematik Siswa SMP melalui Discovery Learning. Edusentris Jurnal Ilmu Pendidikan dan Pengajaran Vol 2 (3), 241-252.

Rahmi, S., Nadia, R., Hasibah, B., \& Hidayat, W. (2017). The Relation between Self-Efficacy toward Math with the Math Communication Competence. Infinity Journal, 6(2), 177182.

Ruqoyyah, S. (2015). Meningkatkan Kemampuan Komunikasi Matematis Siswa SMP Negeri di Kota Cimahi melalui Pendekatan Contextual Teaching and Learning. Skripsi STKIP Siliwangi Bandung. Tidak diterbitkan.

Shoimin, A. (2014). 68 Model Pembelajaran Inovatif dalam Kurikulum 2013. Yogyakarta: ArRuzz Media. 